\title{
Do Functional Problems and Neighborhood Disturbances in and around the Home Trigger Injuries?
}

\author{
Koustuv Dalal*, Charli Eriksson \\ Centre for Injury Prevention and Safety Promotion (CIPSP), School of Health and Medical Sciences, Örebro \\ University, Örebro, Sweden \\ Email: ${ }^{*}$ koustuv2010@hotmail.com
}

Received 16 March 2014; revised 23 April 2014; accepted 1 May 2014

Copyright (C) 2014 by authors and Scientific Research Publishing Inc.

This work is licensed under the Creative Commons Attribution International License (CC BY). http://creativecommons.org/licenses/by/4.0/

cC) (i) Open Access

\section{Abstract}

The study has tried to identify whether poor self-rated health and home and neighbourhood environmental problems trigger injuries. The study used data from the Life \& Health year 2008 survey, a postal questionnaire administered by Statistics Sweden in five administrative regions in central Sweden (Uppsala, Södermanland, Örebro, Varmland and Västmanland). A random sample of 1,060,032 respondents aged 18 - 79 years had participated in the study. Örebro and Varmland region had the highest proportions of injuries. People at their age between 18 to 24 years-malestobacco and alcohol addicted had the highest proportions of injuries. Environmental factors such as disturbances in and around home had emerged as major triggering factors for injuries. Physical functional problems such as problem of buying own food, cooking, dressing-up and walking had been emerged as very strong predicting factors of injuries. Policy makers in Sweden could identify the poor neighborhood, disturb living condition through the housing companies and the cooperative housing societies to control injuries and promote safety.

\section{Keywords}

Unintentional Injuries, Functional Problems and Livelihood Disturbances, Sweden

\section{Introduction}

Injuries are a major public health problem and concern across the world. Injuries have stupendous physiological, psychological, social, familial and economic impacts. World Health Organization's (WHO) working group on

\footnotetext{
"Corresponding author.
} 
the classification of external causes of injury stated: "Injury is a bodily lesion at an organic level resulting from acute exposure to energy (this energy can be mechanical, thermal, electrical, chemical or radiant) interacting with the body in amounts that exceed the threshold of physiological tolerance. In some cases an injury results from an insufficiency of any of the vital elements (in drowning, strangulation, or freezing)" [1].

Plethora of studies have investigated injury risk factors for the last few decades and indicated several factors in relation to host-agents-environments of injuries [2]-[4]. A well-designed injury prevention policy is important based on specific risk factors [5]. Setting appropriate injury prevention policies are major challenges as a result of diversity in the nature of injuries and their risk factors [5]. Effective injury prevention policies have been evidenced for the past few years and indicated that the main challenge is to adapt country-specific injury prevention policy based on etiological framework [6] [7].

In Sweden we have several studies of injury [6] [8]-[10]. However, health status and livelihood environmental problems are under studied especially for injuries. The current study has tried to identify whether poor self-rated health and home and neighbourhood environmental problems trigger injuries.

\section{Methods}

The study used data from the Life \& Health year 2008 survey, a postal questionnaire administered by Statistics Sweden in five administrative regions in central Sweden (Uppsala, Södermanland, Örebro, Varmland and Västmanland). The areas in this study correspond to municipalities including the three largest cities in the sample region (Uppsala, Västerås, and Örebro). Uppsala has ten, Västerås has eight and Örebro has five smaller urban areas. In total 78 areas were included. The survey objective was to generate self-reported information about life and health of the participants. A random sample of 1,060,032 respondents aged 18 - 79 years had participated in the study. More detail of the study is available elsewhere [11].

\subsection{Outcome Variable}

In the current study, unintentional injuries are considered as target variables within past 12 months. Unintentional injuries are also known as accidents. More details of injury definition and types are already described by the World Health Organization [12].

\subsection{Independent Variables}

Demographic factors such as age (in seven groups ranging 18 - 84 years); sex (male/female); education (junior high school, senior high school and college/university); addiction of tobacco and alcohol and employment are used in the study. Senior high school education also includes vocational school trainings.

Experiences of disturbances in home were measured by (regular problem) due to noise problem, due to bad air quality for dis-functioning of exhaust system, due to poor air-conditioning system, due to odor indoor quality. Experiences of neighborhood problems were measured by (regular problem) due to annoying neighbors, due to littered or unclean neighborhood, due to vandalism and graffiti and other reasons. All variables have dichotomous response option (Yes/No).

Self reported functional inabilities were measured by problem of buying own food, problem in cooking, problem in dress-up and problem in walking. All variables have dichotomous response option (Yes/No).

\subsection{Statistical Analysis}

The proportions were used to examine the cross-relationships between dependent (injury) and independent variables (demographics, functional problems and experience of various disturbances in and around home). To identify the regional burden of injury, proportions of injuries in each of five administrative regions were estimated. To better understand the effect of age on functional activity and injuries another controlled cross relation analysis was performed and presented by text. Multivariate logistic regressions were employed to study the potential association between target variable (injuries) and all independent variables. Confidence interval (CI) was measured at 95\% level. Data were analyzed by using IBM SPSS.

\section{Results}

In total 1,060,032 respondents participated in the study (51\% women and $49 \%$ men). Among the participants 
eight percent had injuries in the past twelve months. Majority of the injuries occurred at home, during walking, during maintenance work at home or garden. Örebro and Varmland region had highest proportions of injuries. People at their age between 18 to 24 years, male, tobacco and alcohol addicted had highest proportions of injuries (Table 1).

Environmental factors such as disturbances in and around home had emerged as major triggering factors for injuries. Table 2 reflects that regular experience of disturbances in home such as noise problem, bad exhaust system, bad air conditioning system, bad indoor smell as well as neighborhood problems such as annoying neighbors, littered or uncleaned neighborhood, graffiti and vandalism were strong triggering factors of injuries.

Physical functional problems such as problem of buying own food, cooking, dress up and walking had been emerged as very strong predicting factors of injuries. Table 3 indicates that persons with such functional problems have very high percentage of injuries compared to normal persons.

Only for the age group 75 - 84, the effect of functional activities on injuries had a slight elevated proportions: Problem in buying own food 13\%, Problem in cooking 14\%, Problem in dress up 19\%, Problem in walking $15 \%$ (vs. $12 \%, 13 \%, 17 \%$ and $15 \%$ for general population, respectively).

Logistic regression after controlling all confounding effects indicates that male, senior high school educated persons, tobacco and alcohol addicted persons are more likely to be injured than female, college/university educated persons, non-addicted persons (Table 4). Compared to persons over 75 years, their junior groups are less likely to get injured.

Table 1. Demographics of injuries in five Swedish administrative regions.

\begin{tabular}{|c|c|c|}
\hline Variables & $\mathrm{n}$ & Proportion Injured \\
\hline \multicolumn{3}{|l|}{ Age $^{*}$} \\
\hline 18 - 24 years & 110,851 & $11.8 \%$ \\
\hline 25 - 34 years & 158,763 & $8.2 \%$ \\
\hline 35 - 44 years & 172,874 & $8 \%$ \\
\hline $45-54$ years & 175,259 & $8.2 \%$ \\
\hline 55 - 64 years & 213,505 & $6.9 \%$ \\
\hline 65 - 74 years & 140,488 & $5.7 \%$ \\
\hline 75 - 84 years & 88,292 & $8.3 \%$ \\
\hline \multicolumn{3}{|l|}{ Sex ${ }^{*}$} \\
\hline Female & 540,687 & $7.3 \%$ \\
\hline Male & 519,345 & $8.7 \%$ \\
\hline \multicolumn{3}{|l|}{ Education $^{*}$} \\
\hline Junior School & 246,878 & $6.7 \%$ \\
\hline Senior High School & 383,410 & $9.1 \%$ \\
\hline College/University & 403,796 & $7.6 \%$ \\
\hline \multicolumn{3}{|l|}{ Tobacco Addiction ${ }^{*}$} \\
\hline No & 832,261 & $7.7 \%$ \\
\hline Yes & 214,447 & $9 \%$ \\
\hline \multicolumn{3}{|l|}{ Alcohol $^{*}$} \\
\hline No & 465,980 & $7.2 \%$ \\
\hline Yes & 408,711 & $9.4 \%$ \\
\hline \multicolumn{3}{|l|}{ Employment ${ }^{*}$} \\
\hline No & 173,434 & $8 \%$ \\
\hline Yes & 481,850 & $8.5 \%$ \\
\hline \multicolumn{3}{|l|}{ Regions $^{*}$} \\
\hline Uppsala & 246,347 & $7.7 \%$ \\
\hline Södermanland & 201,612 & $7.9 \%$ \\
\hline Örebro & 211,003 & $8.2 \%$ \\
\hline Varmland & 210,407 & $8.2 \%$ \\
\hline Västmanland & 190,663 & $7.8 \%$ \\
\hline
\end{tabular}

Significance level of chi-square test, $\mathrm{p}<0.001$ is denoted by ${ }^{*}$. 
Table 2. Injuries by experiencing disturbances in and around home.

\begin{tabular}{|c|c|c|}
\hline Variables & $\mathrm{n}$ & Proportion injured \\
\hline \multicolumn{3}{|c|}{$\begin{array}{l}\text { Regular experience of disturbances in \& around } \\
\text { home }\end{array}$} \\
\hline \multicolumn{3}{|c|}{ Due to noise problem ${ }^{*}$} \\
\hline No & 736,887 & $7.5 \%$ \\
\hline Yes & 292,648 & $8.9 \%$ \\
\hline \multicolumn{3}{|c|}{ Due to air quality including bad exhaust system ${ }^{*}$} \\
\hline No & 896,896 & $7.7 \%$ \\
\hline Yes & 123,498 & $9.4 \%$ \\
\hline \multicolumn{3}{|c|}{ Due to air condition (warm/cold) ${ }^{*}$} \\
\hline No & 863,636 & $7.5 \%$ \\
\hline Yes & 154,651 & $10 \%$ \\
\hline \multicolumn{3}{|c|}{ Due to bad indoor smell ${ }^{*}$} \\
\hline No & 947,867 & $7.7 \%$ \\
\hline Yes & 72,119 & $10.1 \%$ \\
\hline \multicolumn{3}{|c|}{ Due to annoying neighbors ${ }^{*}$} \\
\hline No & 885,493 & $7.6 \%$ \\
\hline Yes & 139,765 & $10.1 \%$ \\
\hline \multicolumn{3}{|c|}{ Due to unclean/littered neighborhood* } \\
\hline No & 901,324 & $7.8 \%$ \\
\hline Yes & 119,881 & $8.8 \%$ \\
\hline \multicolumn{3}{|c|}{ Due to vandalism \& Graffiti } \\
\hline No & 926,190 & $7.8 \%$ \\
\hline Yes & 94,114 & $9.1 \%$ \\
\hline \multicolumn{3}{|c|}{ Due to other reasons ${ }^{*}$} \\
\hline No & 907,070 & $7.6 \%$ \\
\hline Yes & 91,193 & $10.5 \%$ \\
\hline
\end{tabular}

Significance level of chi-square test, $\mathrm{p}<0.001$ is denoted by ${ }^{*}$.

Table 3. Self reported functional problem as predicting factor of injuries.

\begin{tabular}{ccc}
\hline Variables & $\mathrm{n}$ & Proportion injured \\
\hline $\begin{array}{c}\text { Any functional capacity related } \\
\text { Problem in buying own food } \\
\text { No }\end{array}$ & & \\
Yes & $1,003,819$ & $7.8 \%$ \\
Problem in cooking ${ }^{*}$ & 43,878 & $12.2 \%$ \\
No & & \\
Yes & $1,021,878$ & $7.8 \%$ \\
Problem in dress up ${ }^{*}$ & 25,980 & $13.2 \%$ \\
No & & \\
Yes & $1,036,055$ & $7.9 \%$ \\
Problem in walking & & \\
No & 12,454 & \\
Yes & & $7.8 \%$ \\
\hline
\end{tabular}

Significance level of chi-square test, $\mathrm{p}<0.001$ is denoted by ${ }^{*}$. 
Table 4. Multivariate analysis of injuries by demographics, neighborhood and self reported functional problems.

\begin{tabular}{|c|c|c|c|}
\hline \multirow{2}{*}{ Variables } & \multirow{2}{*}{$\operatorname{Exp}(B)$} & \multicolumn{2}{|c|}{ 99\% C.I. for EXP (B) } \\
\hline & & Lower & Upper \\
\hline \multicolumn{4}{|l|}{ Age } \\
\hline 18 - 24 years & 0.940 & 0.736 & 1.200 \\
\hline 25 - 34 years & 0.623 & 0.489 & $0.794^{*}$ \\
\hline 35 - 44 years & 0.583 & 0.458 & $0.743^{*}$ \\
\hline 45 - 54 years & 0.589 & 0.462 & $0.750^{*}$ \\
\hline 55 - 64 years & 0.525 & 0.413 & $0.669^{*}$ \\
\hline $65-74$ years & 0.388 & 0.296 & $0.509^{*}$ \\
\hline 75 - 84 years & Ref. & & \\
\hline \multicolumn{4}{|l|}{ Sex } \\
\hline Male & 1.273 & 1.238 & $1.310^{*}$ \\
\hline Female & Ref. & & \\
\hline \multicolumn{4}{|l|}{ Education } \\
\hline Junior School & 0.985 & 0.942 & 1.031 \\
\hline Senior High School & 1.096 & 1.066 & $1.127^{*}$ \\
\hline College/University & Ref. & & \\
\hline \multicolumn{4}{|l|}{ Tobacco addiction } \\
\hline No & Ref. & & \\
\hline Yes & 1.084 & 1.052 & $1.117^{*}$ \\
\hline \multicolumn{4}{|l|}{ Alcohol } \\
\hline No & Ref. & & \\
\hline Yes & 1.124 & 1.093 & $1.155^{*}$ \\
\hline \multicolumn{4}{|l|}{ Employment } \\
\hline No & Ref. & & \\
\hline Yes & 1.026 & 0.993 & 1.059 \\
\hline \multicolumn{4}{|c|}{ Experience of disturbances in \& around home } \\
\hline \multicolumn{4}{|c|}{ Due to noise problem } \\
\hline No & Ref. & & \\
\hline Yes & 1.034 & 1.000 & 1.068 \\
\hline \multicolumn{4}{|c|}{ Due to air quality including bad exhaust system } \\
\hline No & Ref. & & \\
\hline Yes & 1.239 & 1.185 & $1.295^{*}$ \\
\hline \multicolumn{4}{|c|}{ Due to air condition (warm/cold) } \\
\hline No & Ref. & & \\
\hline Yes & 1.162 & 1.121 & $1.204^{*}$ \\
\hline \multicolumn{4}{|l|}{ Due to bad indoor smell } \\
\hline No & Ref. & & \\
\hline Yes & 1.017 & 0.966 & 1.070 \\
\hline \multicolumn{4}{|c|}{ Due to annoying neighbors } \\
\hline No & Ref. & & \\
\hline Yes & 1.184 & 1.139 & $1.231^{*}$ \\
\hline \multicolumn{4}{|c|}{ Due to unclean/littered neighborhood } \\
\hline No & Ref. & & \\
\hline Yes & 0.928 & 0.883 & $0.976^{*}$ \\
\hline \multicolumn{4}{|c|}{ Due to vandalism \& Graffiti } \\
\hline No & Ref. & & \\
\hline Yes & 1.075 & 1.020 & $1.134^{*}$ \\
\hline
\end{tabular}




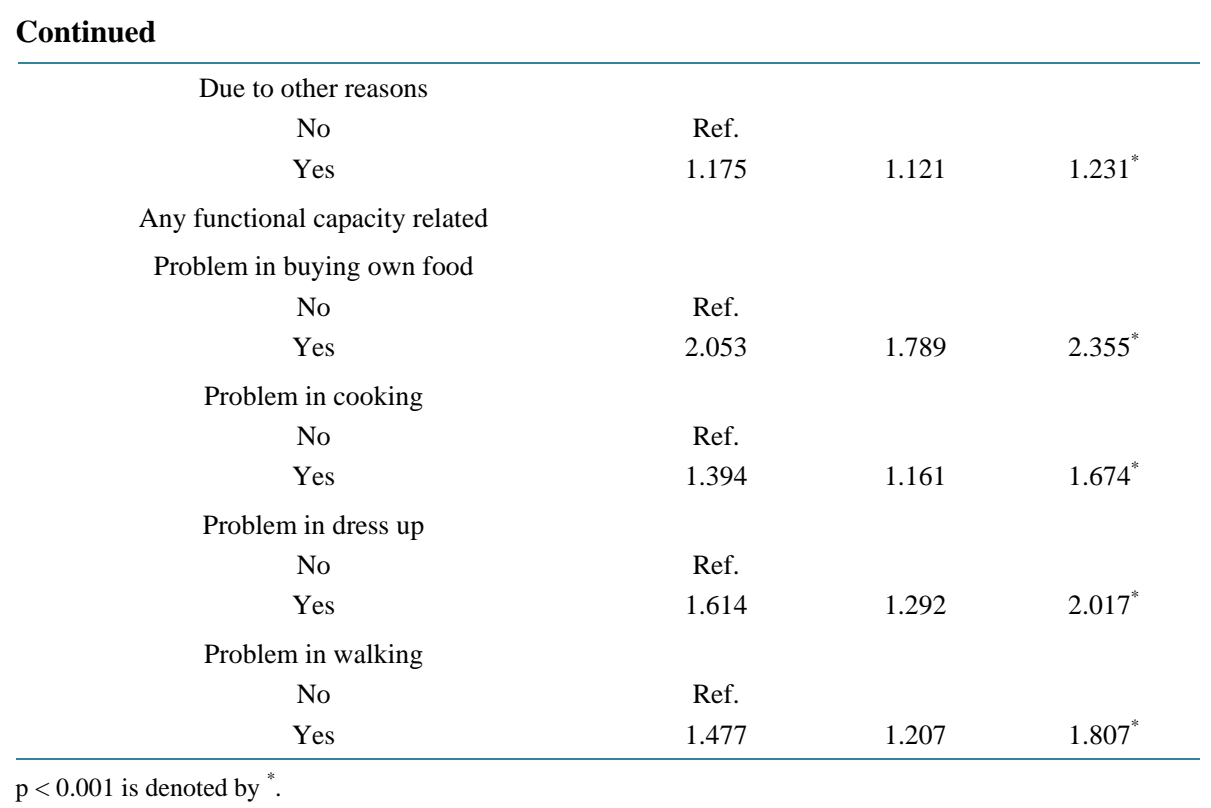

\section{Discussions}

Environmental factors such as disturbances in home and neighborhood are risk factors for injuries. Functional capacity-related problems are important risk factors for injuries. Different age groups, males, educational levels, tobacco addiction and alcoholism are important risk factors for injuries.

Earlier studies had tried to explore neighborhood risk factors for injuries confining the samples within children and adolescents [13] [14]. The current study has focused on general population with a large number of sample sizes in a big geographical area.

Earlier studies have indicated that neighborhood collective efficacy leads to health problems [15] [16]. Current study has revealed that annoying neighbors, imperfect indoor air quality and graffiti in the neighborhood are responsible for injuries. Physical environmental neighborhood factors are associated with increased risk of injuries. After controlling demographic factors these factors are envisaged in the poor socioeconomic neighborhoods. Therefore identifying physical neighborhood and indoor condition could be an important measure for injury prevention. Poor-self rated health such as problem in cooking, dressing, walking and buying self food have emerged as risk factors for injuries. The findings could be novel; however the current study has established poor functional problems as the risk factors. Environment has significant impact on injuries [2]-[4]. The current study has re-established the same principle.

The study has limitation. Firstly, this is a cross-sectional study indulging the problem of assigning causality. However to the best of authors' knowledge, this is the first of its kind to identify physical neighborhood, indoor and self-rated health as risk factors for injuries. Secondly the problem of recall bias is obvious in such a big cross-sectional self-reported study with injury causation. Swedish (and Danish) respondents have a tendency to overrate (vs. reality) their health compared to other European countries [17]. Therefore, the injury causation due to poor self-reported health could be under-estimated in the study. However, this study could be an eye-opener for the Swedish policy makers for better injury control. Sweden has one of the best social supports. Policy makers in Sweden could identify the poor neighborhood, disturbing living condition through the housing companies and the cooperative housing societies. It is worthwhile to prevent injuries in these identified living conditions, instead of spending millions of currencies on the injury treatments.

\section{References}

[1] World Health Organization (1998) Guidelines for Counting and Classifying External Causes of Injuries for Prevention and Control. WHO, Geneva.

[2] World Health Organization (2004) The World Report on Road Traffic Injury. WHO, Geneva.

[3] World Health Organization (2008) The World Report on Child Injury Prevention. WHO, Geneva. 
[4] World Health Organization (2013) The Global Status Report on Road Safety. WHO, Geneva.

[5] Wang, S.M. and Dalal, K. (2013) Safe Communities in China as a Strategy for Injury Prevention and Safety Promotion Programmes in the Era of Rapid Economic Growth. Journal of Community Health, 38, 205-214. http://dx.doi.org/10.1007/s10900-012-9594-4

[6] Lindqvist, K. and Dalal, K. (2002) The Impact of Child Safety Promotion on Different Social Strata in a WHO Safe Community. Journal of Injury and Violence Research, 4, 20-25.

[7] Zhao, Z. and Svanström, L. (2003) Injury Status and Perspectives on Developing Community Safety Promotion in China. Health Promotion International, 18, 247-253. http://dx.doi.org/10.1093/heapro/dag020

[8] Svanström, L., Ekman, R., Schelp, L. and Lindström, A. (1995) The Lidköping Accident Prevention Programme-A Community Approach to Preventing Childhood Injuries in Sweden. Injury Prevention, 1, 169-172. http://dx.doi.org/10.1136/ip.1.3.169

[9] Laflamme, L. and Engström, K. (2002) Socioeconomic Differences in Swedish Children and Adolescents Injured in Road Traffic Incidents: Cross Sectional Study. BMJ, 324, 396-397. http://dx.doi.org/10.1136/bmj.324.7334.396

[10] Svanström, L. (2012) It All Started in Falköping, Sweden: Safe Communities—Global Thinking and Local Action for Safety. International Journal of Injury Control and Safety Promotion, 19, 202-208. http://dx.doi.org/10.1080/17457300.2012.696661

[11] Liv \& Hälsa (2008). http://www.orebroll.se/Files-sv/Örebro\%20läns\%20landsting/Vård\%20och\%20hälsa/Folkhälsa/Liv\%20och\%20hälsa\% 20vuxna/Rapporter/Liv_o_halsa_2012.pdf?epslanguage=sv

[12] World Health Organization (2002) The Injury Chart Book: A Graphical Overview of the Global Burden of Injuries. Peden, M., McGee, K. and Sharma, G., Eds. WHO, Geneva.

[13] Haynes, R., Reading, R. and Gale, S. (2003) Household and Neighbourhood Risks for Injury to 5 - 14 Year Old Children. Social Science \& Medicine, 57, 625-636. http://dx.doi.org/10.1016/S0277-9536(02)00446-X

[14] Reading, R., Langford, I.H., Haynes, R. and Lovett, A. (1999) Accidents to Preschool Children: Comparing Family and Neighbourhood Risk Factors. Social Science \& Medicine, 48, 321-330. http://dx.doi.org/10.1016/S0277-9536(98)00311-6

[15] Cohen, D., Mason, K., Bedimo, A., Scribner, R., Basolo, V. and Farley, T. (2003) Neighborhood Physical Conditions and Health. American Journal of Public Health, 93, 467-471. http://dx.doi.org/10.2105/AJPH.93.3.467

[16] Cohen D., Farley, T. and Mason, K. (2003) Why Is Poverty Unhealthy? Social and Physical Mediators. Social Science and Medicine, 57, 1631-1641. http://dx.doi.org/10.1016/S0277-9536(03)00015-7

[17] Jürges, H. (2007) True Health vs Response Styles: Exploring Cross-Country Differences in Self-Reported Health. Health Economics, 16, 163-178. http://dx.doi.org/10.1002/hec.1134 